\title{
The Effects of Angiotensin II, Saralasin, and Furosemide on Inactive Renin in the Fetal Lamb
}

\author{
SHARON SIEGEL ${ }^{(25)}$ AND TERRY PARKHILL \\ Division of Nephrology, University of California, Los Angeles, California, USA
}

\begin{abstract}
Summary
The effects of angiotensin II, saralasin, and furosemide on plasma prorenin (inactive renin, cryoactivated, and trypsin activated) were studied in the fetal lamb. Cryorenin and trypsinactivated renin decreased from $4.0 \pm 1.0 \mathrm{ng} / \mathrm{ml} / \mathrm{hr}$ of plasma renin activity (PRA) and $7.3 \pm 1.0$ to $0.05 \pm 0.01$ and $1.7 \pm 1.0(P<$ 0.01 ), respectively, after $15 \mathrm{~min}$ of angiotensin II infusion; active renin did not statistically decrease. Cryoactivated and trypsinactivated renin increased from $2.2 \pm 0.5 \mathrm{ng} / \mathrm{ml} / \mathrm{hr}$ (mean \pm S.E.) and $4.9 \pm 0.9$ of PRA to $4.6 \pm 1.0$ and $8.5 \pm 1.5$, respectively, after $30 \mathrm{~min}(P<0.05)$ of the saralasin $(10 \mu \mathrm{g} / \mathrm{kg} / \mathrm{min})$ infusion, whereas active renin showed no change. Furosemide increased cryorenin and trypsin-activated renin in parallel to active renin from $2.9 \pm 1.1 \mathrm{ng} / \mathrm{ml} / \mathrm{hr}$ and $6.9 \pm 1.5$ of PRA to $5.0 \pm 1.0$ and $11.2 \pm 1.5$ at $65 \mathrm{~min}$, respectively $(P<0.05)$. These data show that prorenin levels are high in the fetal lamb, angiotensin II can inhibit prorenin but not renin, and a negative feedback loop exists between angiotensin II and prorenin, but not renin.
\end{abstract}

\section{Speculation}

There are inconsistent responses of prorenin and active renin to stimuli which control active renin secretion in the fetal lamb. Does prorenin have a discrete secretion control mechanism separate from renin and play a role in the fetus?

Inactive forms of circulating plasma renin can be converted in vitro to active renin by acid (11), cryoactivation $(16,18,19)$, trypsin (14), and urinary kallikrein (17). Inactive renin has been found in normal and hypertensive human subjects $(6,7,11,16$ $20)$ and in anephric patients $(20,21,24)$. Several investigators $(4$ $9,10,23$ ) have described inactive forms of renin of higher molecular weight in extracts of human and animal kidneys prepared at neutral $\mathrm{pH}$ and with added inhibitors of proteases.

The purpose of this paper is to determine the effects of angiotensin II, saralasin acetate (an angiotensin II inhibitor), and furosemide on inactive renin (prorenin) in relation to renin in the fetal lamb.

\section{MATERIALS AND METHODS}

Five fetal lambs 120 to 130 days gestation and five lambs 115 to 138 days gestation were studied. Pregnant Columbia or Columbia Suffolk date-bred ewes were obtained from a local source and maintained in the vivarium. A uterotomy was performed under spinal anesthesia, and small polyvinyl catheters coated with silicone were inserted into the femoral artery and lateral tarsal vein The fetus was returned to the uterine cavity, and the uterine incision was closed. The maternal abdominal wall was closed in three layers, and the catheters were brought out through a skin tunnel in the posterolateral abdominal wall. All catheters were secured in a small plastic pouch attached to the back of the ewe. The ewes were given ampicillin $500 \mathrm{mg}$ b.i.d., and the fetus was given $150 \mathrm{mg}$ b.i.d. for 5 days after surgery before study. Blood gases and hemoglobin were monitored during each study.

After two baseline samples for plasma renin and prorenin and plasma sodium (experiment 1 ), angiotensin II $(0.25 \mu \mathrm{g} / \mathrm{kg} / \mathrm{min})$ was infused continuously for $30 \mathrm{~min}$. Repeat blood samples were obtained at 15 and $30 \mathrm{~min}$ during the infusion and $30 \mathrm{~min}$ after the infusion. After two baseline samples for plasma renin and prorenin and plasma sodium (experiment 2), saralasin, $10 \mu \mathrm{g} / \mathrm{kg} /$ min, was infused continuously for $30 \mathrm{~min}$. This dose of saralasin increased plasma renin activity (PRA) to maximal levels (22) in the newborn lamb. Repeat blood samples were drawn at 15 and $30 \mathrm{~min}$ during the infusion and $30 \mathrm{~min}$ after the infusion. After two baseline samples for renin and prorenin (experiment 3 ), furosemide, $2 \mathrm{mg} / \mathrm{kg}$, was infused IV over one min. Repeat blood samples were drawn at 20,35 , and 65 min postinfusion. The amount of blood drawn during each study was $4 \%$ of total blood, which was replaced with isotonic saline after each sample. Blood pressure was monitored in all three experiments by Statham transducer and Gould recorder. Plasma renin was measured by radioimmunoassay $(8,13)$ after generation of angiotensin I (PRA). To identify renin-, cryorenin-, and trypsin-activated renin, the plasma sample was divided into three $0.5 \mathrm{ml}$ parts. One $0.5 \mathrm{ml}$ part was measured for renin as PRA; one $0.5 \mathrm{ml}$ part was placed in an ice bath at $4^{\circ} \mathrm{C}, \mathrm{pH} 6.5$, for $48 \mathrm{hr}$ before generation of angiotensin I (PRA) at $37^{\circ} \mathrm{C}$ for one $\mathrm{hr}$ (total renin measurement); one $0.5 \mathrm{ml}$ part received $2 \mathrm{~g} \%$ of trypsin in $0.1 \mathrm{M}$ sodium phosphate buffer, $\mathrm{pH} 7.0$, and was then incubated at $37^{\circ} \mathrm{C}$ for 2 $\mathrm{hr}$, and the reaction stopped by adding $4 \mathrm{~g} \%$ trypsin inhibitor before generation of angiotensin I (PRA) for $1 \mathrm{hr}$ (total renin measurement). Beta mercaptoethanol and 8-hydroxyquinoline were used to prevent destruction of angiotensin I by converting enzyme and angiotensinase activity. Cryorenin is total renin minus active renin. Trypsin activated renin is total renin minus active renin.

Statistics were measured by direct difference $t$ test.

\section{RESULTS}

In Fig. 1, cryorenin decreased from $4.0 \pm 1.0 \mathrm{ng} / \mathrm{ml} / \mathrm{hr}$ of PRA (mean \pm S.E.) to $0.05 \pm 0.01 \mathrm{ng} / \mathrm{ml} / \mathrm{hr}$ after $15 \mathrm{~min}$ of $0.25 \mu \mathrm{g} /$ $\mathrm{kg} / \mathrm{min}$ angiotensin $\mathrm{II}$ infusion $(P<0.02)$ and returned to baseline by $30 \mathrm{~min}$ postinfusion. Trypsin activated renin decreased from $7.32 \pm 1.0 \mathrm{ng} / \mathrm{ml} / \mathrm{hr}$ of PRA to $1.70 \pm 1.0 \mathrm{after} 15 \mathrm{~min}$ of infusion $(P<0.02)$ and returned to baseline. Renin decreased from 4.15 $\pm 0.72 \mathrm{ng} / \mathrm{ml} / \mathrm{hr}$ of PRA to $2.2 \pm 0.63 \mathrm{after} 30 \mathrm{~min}(P>0.05<$ $0.1)$ of angiotensin II infusion and returned to baseline. The mean aortic blood pressure change was $13.80 \pm 1.74 \mathrm{~mm} \mathrm{Hg}$. There was no change in plasma sodium, hemoglobin, $\mathrm{pH}, \mathrm{pCO}_{2}$, or $\mathrm{pO}_{2}$ during the study.

In Figure 2, cryorenin increased from a baseline of $2.23 \pm 0.58$ $\mathrm{ng} / \mathrm{ml} / \mathrm{hr}$ of PRA to $4.68 \pm 1.0(P<0.05)$ after $30 \mathrm{~min}$ of saralasin $(10 \mu \mathrm{g} / \mathrm{kg} / \mathrm{min})$ infusion. Trypsin activated renin increased from $4.95 \pm 0.97 \mathrm{ng} / \mathrm{ml} / \mathrm{hr}$ of PRA to $8.54 \pm 1.50(P<0.05)$ after 30 min. There was no change in active renin. Mean aortic blood pressure, plasma sodium, hemoglobin, $\mathrm{pH}, \mathrm{pO}_{2}$, and $\mathrm{pCO}_{2}$ did not change during the study. 


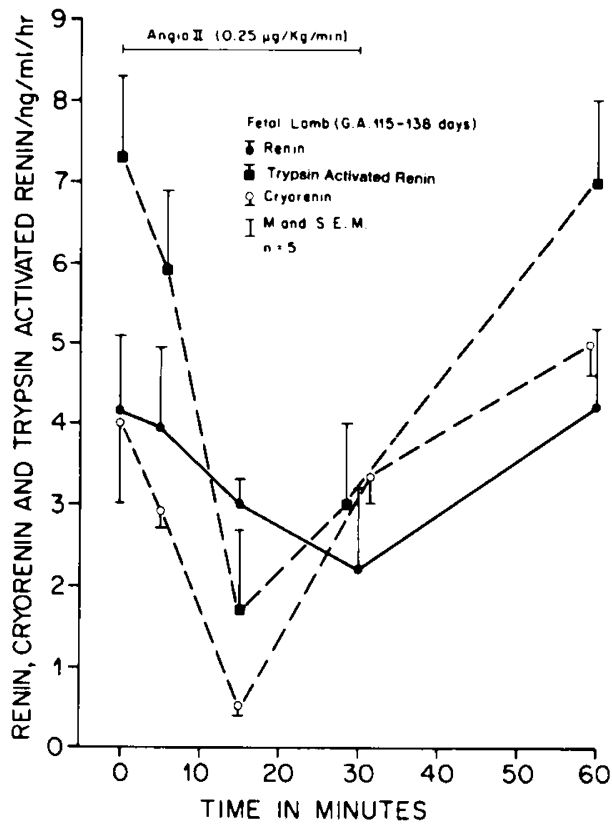

Fig. 1. Cryorenin- and trypsin-activated renin decreased from $4.0 \pm$ $1.0 \mathrm{ng} / \mathrm{ml} / \mathrm{hr}$ of PRA and $7.32 \pm 1.0$ to $0.05 \pm 0.01$ and $1.7 \pm 1.0(P<$ $0.01)$, respectively, after $15 \mathrm{~min}$ of angiotensin II infusion. Renin decreased from $4.15 \pm 0.7 \mathrm{ng} / \mathrm{ml} / \mathrm{hr}$ of PRA to $2.2 \pm 0.6$ after $30 \mathrm{~min}(P>0.05<$ $0.1)$

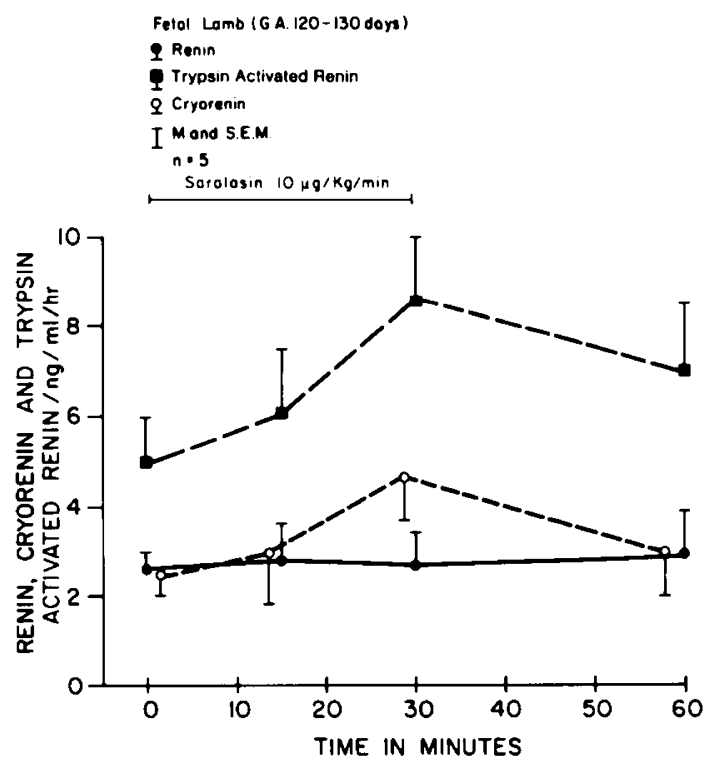

Fig. 2. Cryorenin- and trypsin-activated renin increased from $2.2 \pm 0.5$ $\mathrm{ng} / \mathrm{ml} / \mathrm{hr}$ and $4.9 \pm 0.9 \mathrm{ng} / \mathrm{ml} / \mathrm{hr}$ of PRA to $4.6 \pm 1.0(P<0.05)$ and 8.5 $\pm 1.5(P<0.05)$, respectively, after $30 \mathrm{~min}$ of saralasin infusion, with no change in renin.

Figure 3 shows that cryorenin increased from $2.96 \pm 1.1 \mathrm{ng} /$ $\mathrm{ml} / \mathrm{hr}$ as PRA to $5.07 \pm 1.0$ at $65 \mathrm{~min}(P<0.05)$ postfurosemide infusion. Trypsin-activated renin increased from $6.96 \pm 1.50 \mathrm{ng} /$ $\mathrm{ml} / \mathrm{hr}$ as PRA to $11.28 \pm 1.50$ at $65 \mathrm{~min}(P<0.05)$ postfurosemide. Renin as PRA increased from $2.90 \pm 1.1 \mathrm{ng} / \mathrm{ml} / \mathrm{hr}$ to $5.55 \pm 1.0$ at $65 \mathrm{~min}(P<0.05)$ postfurosemide. There was no change in mean aortic blood pressure, plasma sodium, hemoglobin, $\mathrm{pH}, \mathrm{pO}_{2}$, or $\mathrm{pCO}_{2}$ during the study.

\section{DISCUSSION}

Prorenin levels are high in the fetal lamb. Angiotensin II (Fig 1) decreased prorenin (cryoactivated and trypsin activated) after
$15 \min (P<0.02)$ of a hypertensive dose, $0.25 \mu \mathrm{g} / \mathrm{kg} / \mathrm{min}$. The inhibition of renin by angiotensin II was not statistically significant. This suggests that angiotensin II can inhibit prorenin and not renin in the fetal lamb. It has been shown in the adult human and $\operatorname{dog}(3,12,15)$ and in the newborn lamb (22) that angiotensin II inhibits renin secretion in the kidney by negative feedback.

Cryorenin- and trypsin-activated renin (Fig. 2) increased ( $P<$ 0.05 ) after $30 \mathrm{~min}$ of angiotensin blockade with saralasin, whereas there was no increase in renin. This shows a dissociation in the response of prorenin and active renin. The blood pressure and plasma sodium level did not fall. This suggests that angiotensin II is actively inhibiting prorenin under basal conditions and that the increase in prorenin is not due to a fall in blood pressure or plasma sodium in the fetal lamb. In the newborn lamb (22), renin was increased to maximal levels in response to saralasin.

Furosemide, a drug which stimulates renin at the kidney level (Fig. 3), increased prorenin in parallel to renin in the fetal lamb 120 to 130 days gestation.

These three studies suggest that prorenin is in part of renal origin. Others have shown that prorenin $(5,7)$ is reportedly higher in renal venous plasma than in peripheral plasma in patients with renal artery stenosis. Prorenin release changed in parallel to renin (2) in renal venous blood in response to furosemide, isoproterenol, and propranolol infused into the renal artery of the newborn piglet. Prorenin may at least be, in part, of extrarenal origin because it is present in the plasma of anephric patients $(20,21$, $24)$, although on the average, in lower concentrations. Because both cryoactivation and trypsin activation are indirect methods for measuring prorenin, the maximal concentration of prorenin is not known. The higher PRA values determined by trypsin activation compared to cryoactivation shows that trypsin activation is a more effective measurement of prorenin than cryoactivation and comprises 65 to $70 \%$ of total renin. In previous studies, prorenin has been found to comprise 40 to $80 \%$ of total renin $(1,5,24)$.

Besides the fetus, there have been similar and dissimilar responses in renin and prorenin to various physiologic stimuli in the adult. In hypertensive subjects, prorenin increases in parallel with renin after dietary sodium deprivation $(18,20)$ or administration

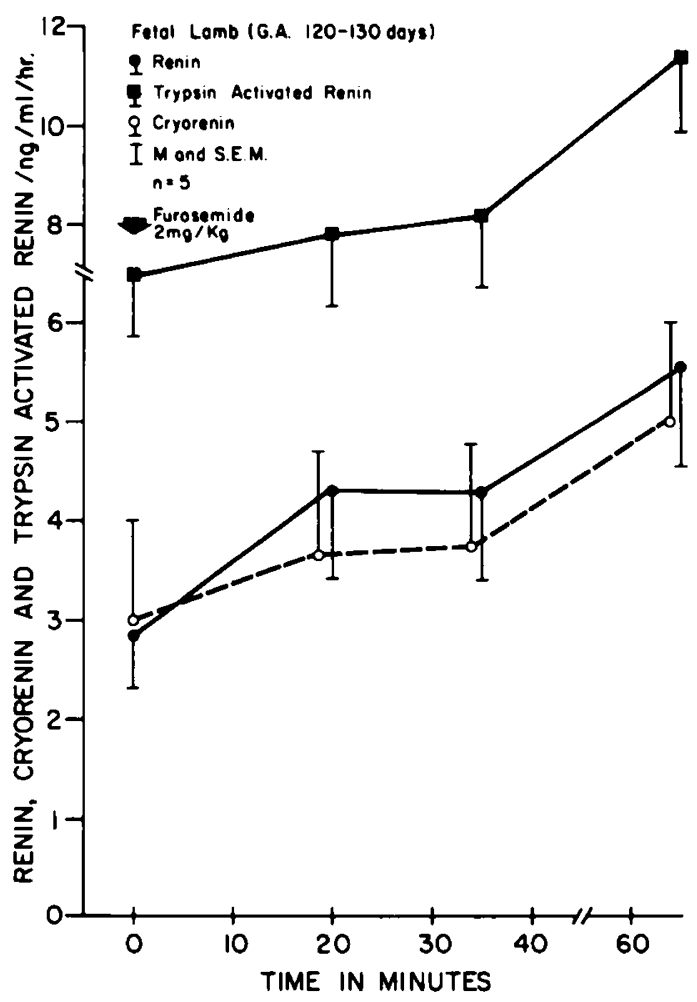

Fig. 3. Cryorenin- and trypsin-activated renin increased in parallel to renin from $2.9 \pm 1.1 \mathrm{ng} / \mathrm{ml} / \mathrm{hr}$ and $6.9 \pm 1.5$ of PRA to $5.0 \pm 1.0(P<$ $0.05)$ and $11.2 \pm 1.5(P<0.05)$, respectively, at $65 \mathrm{~min}$ postfurosemide. 
of diuretics (1). In normal subjects, saline infusion suppresses active but not prorenin (24). Propranolol, which suppresses renin, often causes increases in prorenin $(1,7)$ and the changes in prorenin are inversely related to concurrent changes in systolic blood pressure (1). There is also a reciprocal fall in prorenin after acute stimulation of renin secretion by either isoprenaline infusion or tilting (7). Thus, prorenin, like renin, reacts to falls in blood pressure, adrenergic system regulation, as well as to changes in sodium balance. If it is proposed that prorenin has a discrete secretion control mechanism and a specific physiologic role, then one would expect to observe separate secretion from active renin to the same or different stimuli rather than only intrarenal transformation of inactive renin to its active counterpart. This remains speculation and needs to be defined.

\section{REFERENCES AND NOTES}

I. Atlas, S. A., Sealey, J. E., Laragh, J. H., and Moon, C.: Plasma renin and "prorenin" in essential hypertension during sodium deprivation, beta blockade. and reduced arterial pressure. Lancet, 2: 785 (1977)

2. Bailie, M. D., Derkx, M. H., and Schalekamp, M. A. D. H.: Release of active and inactive renin by the porcine kidney. Circ Res., 44: 32 (1979).

3. Blair-West, J. R., Coghlan, J. R., Denton, D. A., Funder, J. W., Scoggins, B. A.. and Wright, R. D.: Inhibition of renin secretion by systemic and intrarenal angiotensin infusion. Am. J. Physiol., 220: 1309 (1971).

4. Boyd, G. W.: A protein-bound form of porcine renal renin. Circ. Res., 35: 426 (1974).

5. Boyd, G. W.: An inactive higher-molecular-weight renin in normal subjects and hypertensive patients. Lancet, $1: 215$ (1977)

6. Day, R. P., and Luetscher, J. A.: Biochemical properties of big renin extracted from human plasma. J. Clin. Endocrinol. Metab., 40: 1085 (1975).

7. Derkx, F. H. M.. Von Gool. J. M. G., Wenting, G. H., Verhoevon, R. P.: Man. In: A. J. 'T Veld, and M. A. D. H. Schalekamp: Inactive renin in human plasma. Lancet, 2: 496 (1976).

8. Haber, E., Koerner, T., Page, L. B., Kliman, B., and Purnode, A.: Application of a radioimmunoassay for angiotensin $I$ in normal subjects. J. Clin. Endocrinol. Metab., 29: 1349 (1969).

9. Inagami, T., and Murakami, K.: Purification of high molecular weight forms of renin from hog kidney. Circ Res., 41 (Suppl 2): 11 (1977).

10. Leckie, B. J., and McConnel, A.: A renin inhibitor from rabbit kidney. Conversion of a large inactive renin to a smaller active enzyme. Circ. Res., 36: 513 (1975). 11. Lumbers, E. R.: Activation of renin in human amniotic fluid by low $\mathrm{pH}$. Enzymologia, 40: 329 (1971).

12. McDonald, K. M., Taher, S., Aisenbrey, G., de Torrente, A., and Schrier, R. W.: Effect of angiotensin II and angiotensin II inhibitor on renin secretion in the dog. Am. J. Physiol., 228: 1562 (1975).

13. McPhec. R.: Radioimmunoassay Manual. p. 84 (Nichols Institute, San Pedro, 1976).

14. Morris, B. J., and Lumbers, E. R.: The activation of renin in human amniotic fluid by proteolytic enzymes. Biochim. Biophys. Acta, 289: 385 (1972).

15. Noth, R. H., Tan, S. Y., and Mulrow, P. J.: Effects of angiotensin II blockade by saralasin in normal man. J. Clin. Endocrinol. Metab., 45: 10 (1977).

16. Osmond. D. H., Ross, L. N., and Scaiff, K. D.: Increased renin activity after cold storage of human plasma. Can. J. Physiol. Pharmacol., 51: 705 (1973).

17. Sealey, J. E., Atlas, S. A.. Laragh, J. H., Oza, N., and Ryan, J. W.: Human urinary kallikrein converts inactive to active renin and is a possible physiological activator of renin. Nature (Lond.), 275: 144 (1978)

18. Sealey, J. E., and Laragh, J. H.: "Prorenin" in human plasma? Circ. Res., 36/37 (Suppl I): 10 (1975).

19. Sealey, J. E., Moon. C., Laragh, J. H., and Alderman, M.: Plasma prorenin: cryoactivation and relationship to renin substrate in normal subjects. Am. J. Med., 61: 731 (1976)

20. Sealey, J. E., Moon, C., Laragh, J. H., and Atlas, S. A.: Plasma prorenin in normal, hypertensive, and anephric subjects and its effect on renin measurements. Circ Res., 40 (Suppl. I): 41 (1977).

21. Sealey, J. E., White, R. W., Laragh, J. H., and Rubin, A. L.: Plasma prorenin in anephric patients. Circ Res., 4 I (Suppl II): 17 (1977).

22. Siegel, S. R., and Fisher, D. A.: The effects of angiotensin II blockade and nephrectomy on the renin-angiotensin-aldosterone system in the newborn lamb. Pediatr. Res., 13: 603 (1979).

23. Slater, E., and Haber, E.: A large form of renin from normal human kidney. Circulation, 54 (Suppl. 2): 143 (1976).

24. Weinberger, M. H., Wade, M. B., Aoi, W., Usa. T., Dentino, M., Luft, F., and Grim, C. E.: An extrarenal source of "renin-like activity" in anephric man Circ Res., 40 (Suppl. I): I (1977).

25. Requests for reprints should be addressed to: Sharon R. Siegel, M.D., Department of Medicine and Pediatrics, Division of Nephrology, 52-175 Center for the Health Sciences, Los Angeles, California 90024 (USA).

26. This research was supported by Grant 4-444934-58291 from the American Heart Association-Greater Los Angeles Affiliate and by Grant HD 13910 from the National Institute of Child Health and Human Development of the National Institutes of Health.

27. Received for publication July 26, 1979.

28. Accepted for publication March 30, 1980 